九州大学学術情報リポジトリ

Kyushu University Institutional Repository

\title{
Photosynthetic Response and Carboxylation Activity of Enzymes in Leaves and Roots of Water Chestnut, Trapa bispinosa Roxb.
}

Ishimaru, Ken

Laboratory of Practical Botany, Faculty of Agriculture, Kyushu University

Kubota, Fumitake

Laboratory of Practical Botany, Faculty of Agriculture, Kyushu University

Saitou, Kazuyuki

Laboratory of Practical Botany, Faculty of Agriculture, Kyushu University

Nakayama, Mariko

Laboratory of Practical Botany, Faculty of Agriculture, Kyushu University

https://doi.org/10.5109/24130

出版情報: 九州大学大学院農学研究院紀要. 41 (1/2)，pp.57-65，1996-11. Kyushu University バージョン：

権利関係 : 


\title{
Photosynthetic Response and Carboxylation Activity of Enzymes in Leaves and Roots of Water Chestnut, Trapa bispinosa Roxb.
}

\author{
Ken Ishimaru, Fumitake Kubota, Kazuyuki Saitou \\ and Mariko Nakayama \\ Laboratory of Practical Botany, Faculty of Agriculture, \\ Kyushu University, Fukuoka 812-12, Japan \\ (Received July 31, 1996)
}

\begin{abstract}
A water chestnut, Trapa bispinosa Roxb., plant often develops a large scale root system in natural waters. The roots are green colored with chlorophyll and capable of photosynthesis using light energy coming through the water. The production of this plant depends solely on the photosynthesis of these roots until leaves expand on and above the water surface to function in photosynthesis. Interestingly photosynthesis in this plant is carried out under two different environments; by roots in water and by leaves in the atmosphere. We investigated photosynthetic features of green roots in terms of 0 , evolution response and activity of photosynthetic enzymes. Leaf photosynthesis exhibited a $\mathrm{C} 3$ type trait, but in roots photosynthetic system was comparative to that of the submerged type (SUM) showing an increased activity in phosphoenolpyruvate carboxylase (PEPCase) and malate accumulation in root cells at night.
\end{abstract}

\section{INTRODUCTION}

Water chestnut is an annual floating-leaved plant with C3 type photosynthesis, growing in wide areas of natural waters from the tropics to the frigid zone. In Japan, the plants' habitat is commonly found in ponds and lakes from the southern to northern regions. Seeds of water chestnut were previously collected for food. Nowadays the cultivation area is quite restricted that recently water chestnut has been rather regarded as one of the strong weeds growing in eutrophicated waters due to their vigorous growth and high reproductive ability.

Water chestnut has often been used in studies on biomass production (Tsuchiya and Iwaki, 1983, 1984) and ecosystem (Seki et al., 1979; Tsuchiya and Iwaki, 1979; Matsuo et al., 1979; Yamamoto and Seki, 1979), but there are few reports available regarding their yield production. In the genera Trapa, various morphological types are included, and some of them are known to be capable of producing large sized seeds with good taste and with a high starch production ability. A high growth sensitivity to fertilization is one of the features of this plant. An experimental record showed that the seed yield was over 1 ton 10 a in fresh weight when plants were grown in fertilized paddy fields (Arima et al., 1990 and 1992a, b).

Through its entire life process, water chestnut stays in water or floats on the water surface. As water temperature rises in spring, the primary root emerge from the buried seed in soil under water, and new roots differentiate and elongate upward from the first node of the primary root. The cotyledons remain inside the seed coat. Some of the roots enter the soil to stabilize the plant against water flow, while other roots elongate and 
continue branching in water. Also from this first node, stems appear, then elongate upward, during which many leaves and roots are produced from the nodes of the elongating stems. The branching system of water chestnut has been described in detail by Arima et al. (1990). By branching its stem, a water chestnut plant can develop a large scale root system in water, and the elongating stems enable leaves to rise and appear on the water surface.

The roots growing in water play an important role in the biomass production of water chestnut; these roots are green colored with chlorophyll, performing photosynthesis using light energy coming through water. An interesting character for water chestnut is that photosynthesis is conducted in different organs within a plant under two different environments; one is by green roots in water and the other is by leaves floating on the water surface. In the present study, photosynthetic response of green roots was discussed in terms of photosynthetic oxygen evolution and carboxylation activity of two main enzymes.

\section{MATERIALS AND METHODS}

\section{Cultivation of plants}

Two seeds, var. Tobishi or Chinese water chestnut weighing about $20 \mathrm{~g}$ (fresh weight) per seed, were sown in early May 1991 in the soil laid at a depth of $10 \mathrm{~cm}$ under water in a water tank located at the agricultural experiment field of Kyushu University. The tank capacity was $90 \mathrm{~L}$ and the water depth was kept $40 \mathrm{~cm}$ during the experimental period. Chemical compound fertilizer (N:P:K=16:16:16) was applied $10 \mathrm{~g}$ as a basal fertilization to a tank. The experimental cultivation was made using two tanks with four plants.

\section{Measurement of chlorophyll content}

Chlorophyll a and b were extracted from leaves in $95 \%$ ethanol for $48 \mathrm{hr}$ in the dark, and their contents were calculated from absorption rates of the solution measured spectroscopically at 649 and $665 \mathrm{~nm}$, respectively. For determination of chlorophyll contents in green roots, chlorophylls were extracted from the ground root tissue in $80 \%$ acetone, and the obtained solution was measured by the same procedure above.

\section{Measurement of photosynthetic rate of emersed leaves and submerged roots}

Oxygen evolution of leaf

The rate of oxygen evolution was measured in liquid phase with an oxygen electrode system (Rank Brothers, UK). Just before the measurement, four leaf disks $\left(0.3 \mathrm{~cm}^{2} \mathrm{a}\right.$ disk) were punched out from leaves and cut each disk into eight segments. The segments double wrapped with gauze were evacuated and then put in the reaction cell of the oxygen electrode system filled with a $50 \mathrm{mMHEPES}-\mathrm{NaOH}(\mathrm{pH}$ 7.2) that contained 0.5 $\mathrm{mMCaSO}_{4}$. The photosynthetic reaction was initiated by adding $\mathrm{NaHCO}_{3}$ at a final concentration of $20 \mathrm{mM}$, then the rate of 0 , evolution was determined in a photosynthetically saturating light intensity under the controlled temperature.

Oxygen evolution of root

Green roots were cut $10 \mathrm{~mm}$ in length and the cut ends were sealed by quick-drying 
glue and the $\mathrm{O}_{2}$ evolution rate of the prepared materials was measured by the same method described above.

\section{Measurement of activities of ribulose bisphosphate carboxylase (RuBPCase) and phosphoenolpyruvate carboxylase (PEPCase)}

All the procedures for enzyme extraction were carried out at $4^{\circ} \mathrm{C}$ or less. Tissue segments of leaf or root were quickly ground with a chilled mortar and pestle in one volume of ice-cold medium that contained $50 \mathrm{mM}$ Tris- $\mathrm{HCl}(\mathrm{pH} 7.7), 0.1 \mathrm{mM}$ EDTA, 10 $\mathrm{mM} \mathrm{MgCl}_{2}, 5 \mathrm{mM}$ dithiothretiol (DTT), $10 \mathrm{mM} \mathrm{NaHCO}_{3}$ and $3 \%$ polypyrolidone (PVP). The homogenate obtained was centrifuged at $15,000 \mathrm{rpm}$ for $5 \mathrm{~min}$, and the resulting supernatant was used as the preparation for enzymatic assay.

For measurement of activity of RuBPCase, the supernatant of $50 \mu \mathrm{L}$ was mixed with $440 \mu \mathrm{L}$ of the reaction solution that contained $25 \mathrm{mM} \mathrm{MgCl}_{2}, 5 \mathrm{mM}$ DTT, $20 \mathrm{mM} \mathrm{Na}^{14} \mathrm{CO}_{3}$ $(0.061 \mathrm{ci} / \mathrm{mol}$ ) $), 100 \mathrm{mMTris}-\mathrm{HCl}(\mathrm{pH} \mathrm{8.2})$. Then reaction was started by applying $20 \mathrm{mM}$ $\mathrm{RuBP}$ to the mixture, and after one min the reaction was stopped by applying $100 \mu \mathrm{L} 2 \mathrm{~N}$ HCI to it. The fluid of $80 \mu \mathrm{L}$ of this was put into a vial and dried. Scintillator (ASC-2, Amersham) of $2 \mathrm{~mL}$ was added to this, then the radioactivity was measured with a liquid scintillation counter (Tricarb, 2250CA, Packard, USA).

The reaction solution used for measurement of PEPCase activity contained $5 \mathrm{mM}$ $\mathrm{MgCl}_{2}, 0.2 \mathrm{mM}$ nicotinamide adenine dinucleotide (NADH), 6 International Unit (I.U.) malate dehydrogenase, $4 \mathrm{mM}$ DTT, $25 \mathrm{mM} \mathrm{NaH}^{14} \mathrm{CO}_{3}(0.061 \mathrm{ci} / \mathrm{mol})$ and $100 \mathrm{mM}$ Tris- $\mathrm{HCl}$ (pH 8.0). The extraction fluid of $100 \mu \mathrm{L}$ and the reaction solution of $350 \mu \mathrm{L}$ were mixed and reacted for three min at $30^{\circ} \mathrm{C}$ in advance. The reaction started upon applying $50 \mu \mathrm{L}$ of $25 \mathrm{mMPEPCase}$ was stopped after one min by adding $100 \mu \mathrm{L} 2 \mathrm{~N} \mathrm{HCl}$. The measurement of radioactivity was conducted by the same method as described above for RuBPCase activity determination.

\section{Measurement of malate content in roots}

Malate was extracted from $0.3 \mathrm{~g}$ green roots in $5 \mathrm{~mL} 5 \%$ perchloric acid (PCA) in an ice-cold mortar and electronic conductivity of the solution was measured with a liquid chromatography. As a column CDD-6A (Shimadzu, Japan) was used and $1 \mathrm{mM}$ PCA was passed through it at a velocity of 0.7 to $0.8 \mathrm{~mL} / \mathrm{min}$. The calibration line was obtained from the standard malate solutions of $0.2,0.5$ and $1.0 \mathrm{mM}$.

\section{RESULTS AND DISCUSSION}

Seasonal changes in chlorophyll $\mathrm{a}+\mathrm{b}$ content $(\mathrm{chl} \mathrm{a}+\mathrm{b})$ in green roots and leaves are shown in Fig. 1. Chl $\mathrm{a}+\mathrm{b}$ content determined on July 21 differed slightly between roots and leaves, but the difference increased with growth and after late August, leaf chl $a+b$ was 1.2 to 2.0-times higher than that of roots. During seed maturation after flowering in middle August, photosynthesis may also increase with increasing chlorophyll content of emersed leaves.

Although a slight increase was detected in root chl $a+b$ measured on August 27, in summer underwater green roots can not receive sufficient light energy because the water 


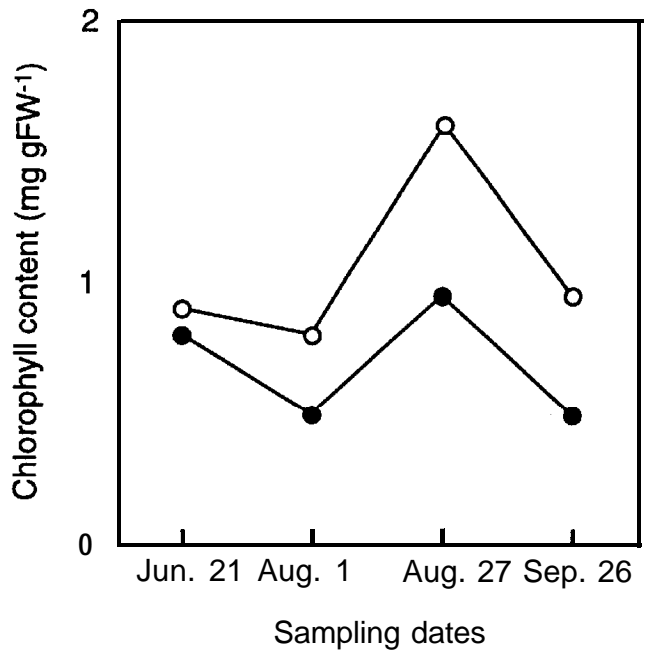

Fig. 1. Seasonal changes in chlorophyll $a+b$ content in green roots $(\boldsymbol{O})$ and leaves $(\mathbf{0})$.

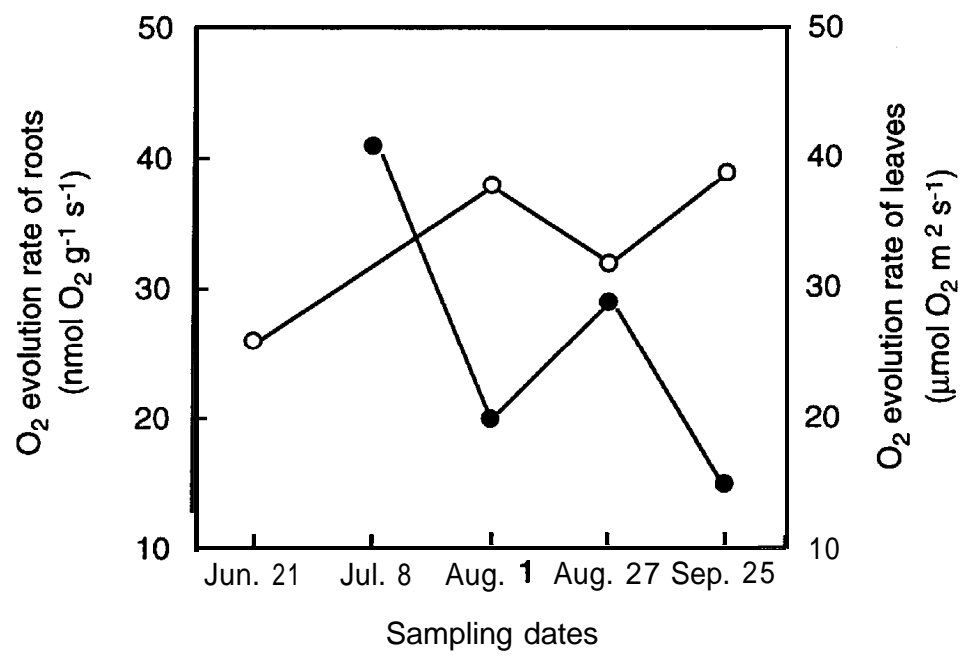

Fig. 2. Seasonal changes in the photosynthetic $\mathrm{O}_{2}$ evolution rate of green roots (O) and leaves (0). 
surface is covered with expanded leaves. Hence the photosynthetic production by roots should be greatly reduced under this condition. The decrease in root chlorophyll content observed in autumn seems to be chiefly caused by shading and senescence. Chlorophyll a and $b$ ratio did not show a significant difference between roots and leaves, and the content of chl a was 2.5 to 3.0 times higher than that of chl b over the growth season.

Fig. 2 shows the photosynthetic $\mathrm{O}_{2}$ evolution rates of roots per unit weight and of leaves per unit leaf area. Leaf photosynthetic rate increased with growth from spring to summer, whereas that of roots decreased. The relative importance of leaf photosynthesis may intensify due to the increased sink demand from flowering to maturity.

The water surface often reaches high temperatures depending on climatic cir-
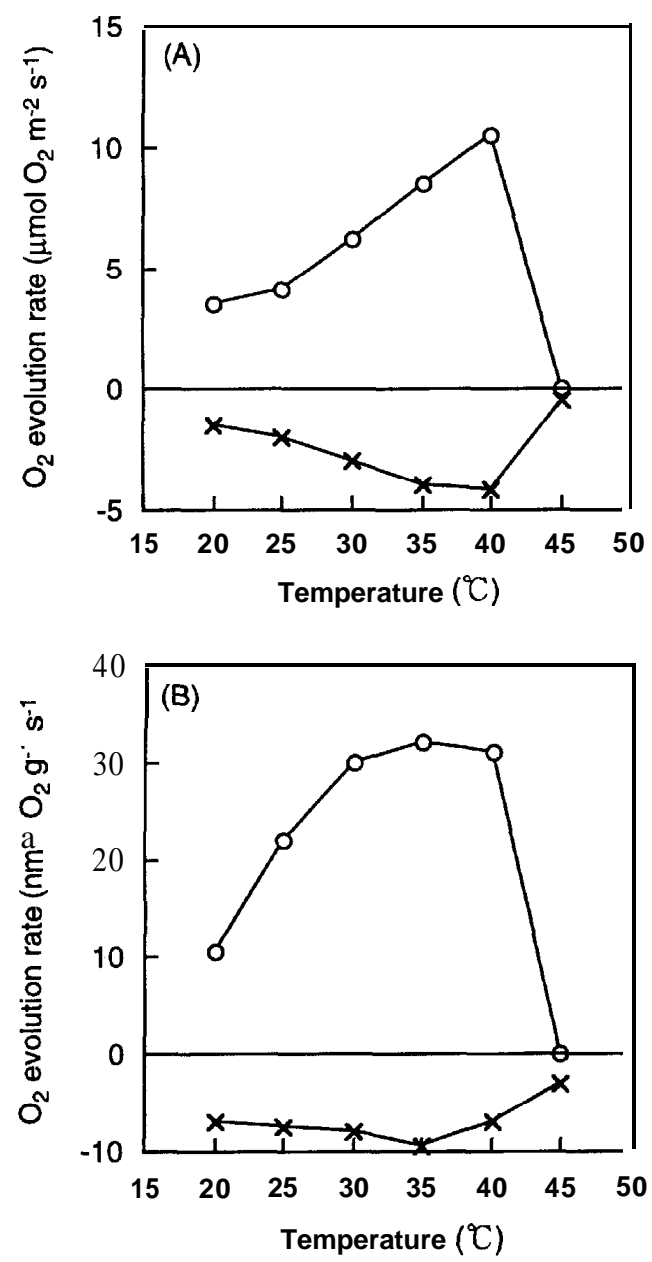

Fig. 3. Effects of temperature on the photosynthetic (0) and the dark respiration rate $(\mathrm{X})$ of leaves $(\mathrm{A})$ and green roots $(\mathrm{B})$. 
cumstances; the difference in temperature between the surface and the underwater was about $3^{\circ} \mathrm{C}$ at noon of a clear day in summer. This is thought to affect the photosynthetic characteristics of leaves and roots. Fig. 3 (A and B) shows the photosynthetic responses of roots and leaves to temperature. Leaf photosynthetic rate increased as water temperature rised to $40^{\circ} \mathrm{C}$, while in roots photosynthetic rate reached a maximum at $35^{\circ} \mathrm{C}$ and then slightly decreased at $40^{\circ} \mathrm{C}$. This finding seems to indicate that leaves are more adaptable to high temperature in photosynthesis compared to roots, but their difference in photosynthetic response pattern was not significant.

The optimal temperature for photosynthesis is usually detected at about $30^{\circ} \mathrm{C}$ in $\mathrm{C} 3$ plants, but water chestnut showed a relatively high optimal point compared to this. It is still not clearly defined whether this trait is common to water chestnut species or not. Also the dark respiration rate increased up to $40^{\circ} \mathrm{C}$ in leaves whereas the maximum rate was observed at $30^{\circ} \mathrm{C}$ in roots. These photosynthetic and respiratory responses were almost similar in pattern at the other growth stages.

The comparison of photosynthetic rate per unit chlorophyll weight between roots and leaves is shown in Fig. 4. The ratio of leaf to root in photosynthesis was 100:22 at the optimal temperatures of 35 to $40^{\circ} \mathrm{C}$, and it increased with decreasing water temperature, being $100: 7.6$ at $15^{\circ} \mathrm{C}$. It may be considered that the leaf photosynthesis was far higher than root photosynthesis because the $\mathrm{O}_{2}$ evolution of leaf was measured here without stomatal resistance whereas the gas exchange of root was restricted by root epidermis. If the root photosynthesis can be measured without this restriction, the photosynthetic rate may yield considerably higher rates. Moreover a high level of chlorophyll content shown in Fig. 1 may indicate high potential of root photosynthesis.

In natural waters like ponds and lakes, stems of water chestnut elongate several meters after germination from the bottom to the water surface. During this growth period

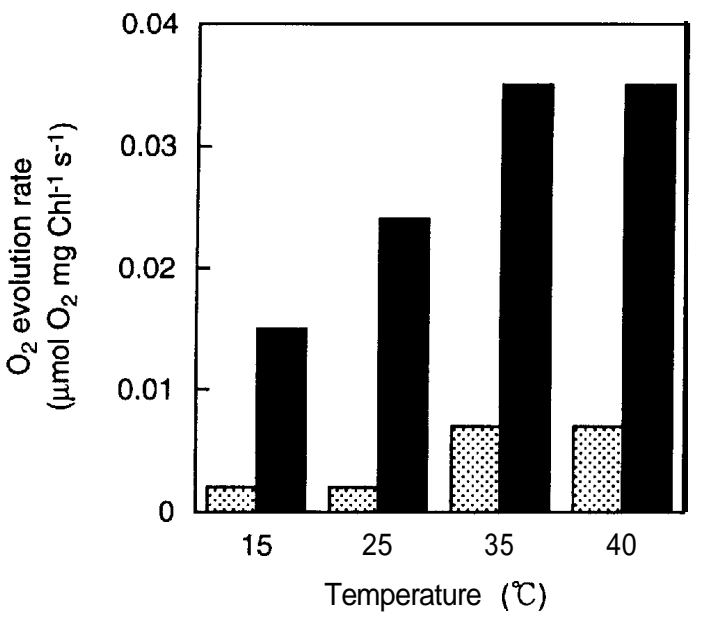

Fig. 4. Comparison of photosynthetic rate per unit chlorophyll weight between green roots (n) and leaves ( 
Table 1. RuBPCase and PEPCase activities in leaves and green roots.

\begin{tabular}{lcc}
\hline & $\begin{array}{c}\text { RuBPCase } \\
\left(\mu \mathrm{mol} \mathrm{mg} \mathrm{Chl} \mathrm{s}^{-1}\right)\end{array}$ & $\begin{array}{c}\text { PEPCase } \\
\left(\mathrm{x} 10^{2} \mu \mathrm{mol} \mathrm{mg} \mathrm{Chl} \mathrm{S} \mathrm{S}^{1}\right)\end{array}$ \\
\hline Leaf & $\begin{array}{c}1.127 \pm 0.291 \\
(100)\end{array}$ & $\begin{array}{c}1.646 \mathrm{t} 0.397 \\
(100)\end{array}$ \\
Green root & $4.889 \pm 1.109^{* *}$ & $5.313 \pm 1.692^{*}$ \\
& $(434)$ & $(323)$ \\
\hline
\end{tabular}

The symbols $*$ and $* *$ indicate a significance at $5 \%$ and $1 \%$, respectively, at t-test. Numerals in parentheses indicate the ratios to those of leaves.

the production should be solely dependent on the photosynthesis performed by green roots. The photosynthetic rates of roots shown in Fig. 4B were measured in $\mathrm{CO}_{2}$ saturating solution, but in natural waters the $\mathrm{CO}$, concentration is lower and hence photosynthesis could be reduced due to the deficiency of substrate. The main role of green roots is regarded as re-fixing of $\mathrm{CO}_{2}$ evolved in respiration. By photosynthetic production based on this endogenous $\mathrm{CO}$, source the substance consumed by respiration is compensated, so that the plant can grow without exhausting the substance pool in the endosperm until leaves reach the water surface to begin photosynthesis.

It has been reported that the activity of photosynthetic enzymes in submerged aquatic plants is different from that of aerial plant, and the accumulation of malate is another feature in aquatic plants (Browse et $a l ., 1977$ and 1979, Winter, 1978). In CAM plants $\mathrm{CO}$, is taken in at night by increased activity of PEPCase and the product is accumulated as malate in vacuoles. In the day time malate is decarboxylated and produced $\mathrm{CO}$, is fixed by RuBPCase. The photosynthetic trait of aquatic plants resembling that of CAM plants is called SUM type photosynthesis. Activities of main photosynthetic enzymes, PEPCase and RuBPCase, in leaves and roots are listed in Table 1. RuBPCase and PEPCase activities per unit chlorophyll weight in roots showed 4.34and 3.23-fold higher than in leaves, respectively. The increase in PEPCase activity in roots agrees with the general understanding for submerged plants.

In order to understand the photosynthetic responses of roots and leaves from another point of view, the diurnal changes in $\mathrm{O}_{2}$ evolution rate and malate concentration are shown in Fig. 5 (A and B). Leaf photosynthetic rate was almost constant throughout the day though it showed a little depression at night (Fig. 5A). These values were measured in liquid phase without stomatal resistance, hence the diurnal variation is independent of the movement of stomata showing a direct relation to the photosynthetic potential in mesophyll. On the other hand, a distinct diurnal change was observed in root photosynthetic rate, which increased in the day time and decreased at night, and malate content in roots increased at night and decreased in the day time (Fig. 5B).

In a water chestnut plant emersed leaves perform C3 type photosynthesis while the root photosynthesis is characteristically that of the SUM type. Working of the plural 

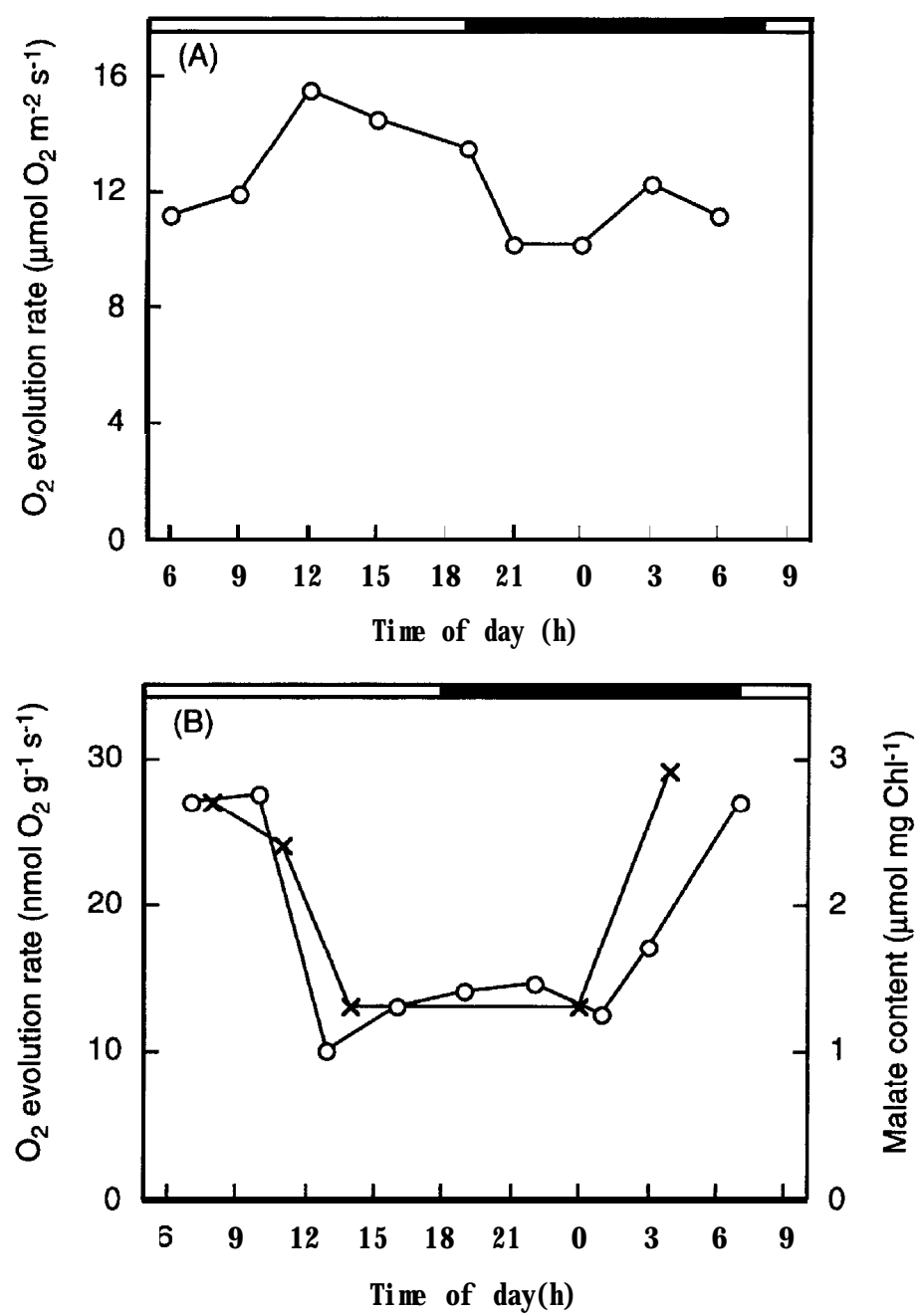

Fig. 5. Diurnal changes in $\mathrm{O}_{2}$ evolution rate $(\mathbf{0})$ and malate content $(\mathrm{X})$ of leaves (A) and green roots (B).

photosynthetic systems in a plant could contribute to the increase of the biomass production efficiency of water chestnut. Bitonti et al. (1996) noted that the buds formed in the floating part and submerged part of a water chestnut plant undergo changes in genome organization in order to make adaptation in different environments. The photosynthesis in roots of water chestnut is also taken up as an interesting subject related to the genetic field. 


\section{REFERENCES}

Arima, S., N. Tanaka and F. Kubota 1990 Growth of vegetative organs in water chestnut, (Trapa bispinosa Roxb.). Bull. Fac. Agr., Saga Univ., 68: 49 -64

Arima, S., J. Harada and N. Tanaka 1992a Growth and yield performance of the water chestnut (Trapa bispinosa Roxb.). II. Relationship among canopy formation of emersed leaves, flowering and the number of valuable fruits. Jpn. J. Crop Sci.,62: 229-234 (in Japanese)

Arima, S., N. Tanaka, J. Harada, K. Matsumoto and F. Kubota 1992b Growth and yield performance of the water chestnut (Trapa bispinosa Roxb.). I. Relationship among yield, yield components and change of number of rosettes. Jpn. J. Crop Sci., 62: 223-228 (in Japanese)

Bitonti, M.B., R. Cozza, G. Wang, M. Ruffini-Castiglione, S. Mazzuca, S. Castiglione, F. Sala and A.M. Innocenti 1996 Nuclear and genomic changes in floating and submerged buds and leaves of heterophyllous waterchestnut (Trapa natans). Physiol. Plant., 97: 21-27

Browse, J. A., F. I. Dromgoole and J. M. A. Brown 1977 Photosynthesis in the aquatic macrophyte Egria densa. I. ${ }^{14} \mathrm{CO}_{2}$ fixation at natural CO, concentrations. Aust.J. Plant Physiol., 4: 169-176

Browse, J. A., J. M. A. Brown and F. I. Dromgoole 1979 Photosynthesis in the aquatic macrophyte Egria densa. II. Effects of inorganic carbon conditions on ${ }^{17} \mathrm{C}$ fixation. Aust.J. Plant. Physiol., 6: 1-9

Matsuo, S., H. Yamamoto, H. Nakano and H. Seki 1979 Impact of nutrient enrichment in a waterchestnut ecosystem at Takahama-iri Bay of Lake Kasumigaura, Japan. III.Degradation of waterchestnut. Water, Air, and Soil Pollution, 12: 511-517

Seki, H., M. Takahashi and S. Ichimura 1979 Impact of nutrient enrichment in a waterchestnut ecosystem at Takahama-iri Bay of Lake Kasumigaura, Japan. I. Nutrient influx and phytoplankton bloom. Water, Air, and Soil Pollution, 12: 383-391

Tsuchiya, T. and H. Iwaki 1979 Impact of nutrient enrichment in a waterchestnut ecosystem at Takahama-iri Bay of Lake Kasumigaura, Japan. II. Role of waterchestnut in primary productivity and nutrient uptake. Water, Air, and Soil Pollution, 12: 503-510

Tsuchiya, T. and H. Iwaki 1983 Biomass and net primary production of a floating-leaved palnt, Trapa natans, community in Lake Kasumigaura, Japan. Jap. J.Ecol., 33: 47-54

Tsuchiya, T. and H. Iwaki 1984 Seasonal changes in photosynthesis and primary production of floatingleaved plant ,Trapa natans L., community in Lake Kasumigaura, Jap. J.Ecol., 34: 367-374

Winter, K. 1978 Short-term fixation of ${ }^{14}$ cabon by the submerged aquatic angiosperm Pota mogeton pectinataus. J. Exp. Bot., 29: 1169-1172

Yamamoto, H. and H. Seki 1979 Impact of nutrient enrichment in a waterchestnut ecosystem at Takahama-iri Bay of Lake Kasumigaura, Japan. IV. Population dynamics of secondary producers as indicated by chitin. Water, Air, and Soil Pollution, 12: 519-527 